\title{
ANALYSIS OF METHANE BIODEGRADATION BY Methylosinus trichosporium OB3b
}

\author{
Andréa dos Santos Rodrigues, Belkis Valdman e Andréa Medeiros Salgado \\ Departamentos de Engenharia Bioquímica e de Engenharia Química, Escola de Química, Universidade Federal do Rio de Janeiro, \\ Rio de Janeiro, RJ, Brasil.
}

Submitted: June 11, 2008; Returned to authors for corrections: September 04, 2008; Approved: March 31, 2009.

\begin{abstract}
The microbial oxidation of methane in the atmosphere is performed by methanotrophic bacteria that use methane as a unique source of carbon and energy. The objective of this work consisted of the investigation of the best conditions of methane biodegradation by methanotrophic bacteria Methylosinus trichosporium OB3b that oxidize it to carbon dioxide, and the use of these microorganisms in monitoring methods for methane. The results showed that $M$. trichosporium OB3b was capable to degrade methane in a more effective way with an initial microorganism concentration of $0.0700 \mathrm{~g} \cdot \mathrm{L}^{-1}$, temperature of $30^{\circ} \mathrm{C}, \mathrm{pH} 6.5$ and using $1.79 \mathrm{mmol}$ of methane. In these same conditions, there was no bacterial growth when $2.69 \mathrm{mmol}$ of methane was used. The specific rate of microorganism growth, the conversion factor, the efficiency and the volumetric productivity, for the optimized conditions of biodegradation were, respectively, $0.0324 \mathrm{~h}^{-1}, 0.6830$ gcells $/ \mathrm{gCH}_{4}, 73.73 \%$ and $2.7732 .10^{-3}$ gcells/L.h. The final product of methane microbiological degradation, carbon dioxide, was quantified through the use of a commercial electrode, and, through this, the grade of methane conversion in carbon dioxide was calculated.
\end{abstract}

Key words: methane, biodegradation, methanotrophic bacteria, Methylosinus trichosporium OB3b.

\section{INTRODUCTION}

Methane is one of the atmospheric trace gases that participates in photochemical reactions that occur in the atmosphere and it shows a great capacity for absorption of infrared radiation emitted by the surface of the planet $(16,18)$. This gas is produced by methanogenic bacteria under anaerobic conditions and it is consumed by methane oxidizing bacteria (methanotrophic bacteria) in aerobic environments $(13,16)$. Moreover, methane is a greenhouse

\footnotetext{
ABBREVIATIONS

$\mathrm{DO}_{600}$ : optical density at $600 \mathrm{~nm}$; MMO: methane monooxigenase; $\mathrm{M}_{\mathrm{Sf}}$ : final amount of substrate (g); $\mathrm{M}_{\mathrm{so}}$ : initial amount of substrate $(\mathrm{g})$;

$\mathrm{M}_{\mathrm{Xf}}$ : final amount of biomass (g);

$\mathrm{M}_{\mathrm{Xo}}$ : initial amount of biomass (g);

$P$ : conversion of $\mathrm{CH}_{4}$ in $\mathrm{CO}_{2}(\%)$

$\mathrm{Q}_{\mathrm{p}}$ : volumetric productivity (g/L.h);

$\mathrm{t}$ : time (h);

T: temperature $\left({ }^{\circ} \mathrm{C}\right)$;

$\mathrm{X}$ : cellular concentration $\left(\mathrm{g} . \mathrm{L}^{-1}\right)$;
}

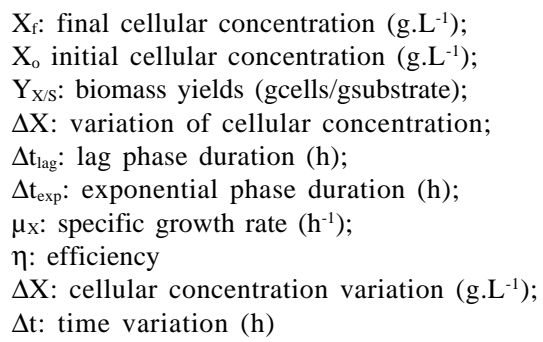

*Corresponding Author. Mailing address: Departamentos de Engenharia Bioquímica e de Engenharia Química, Escola de Química, Universidade Federal do Rio de Janeiro, Rio de Janeiro, RJ, Brasil.; E-mail: andrearodrigues11@infolink.com.br 
gas whose atmospheric concentration has been increasing significantly.

Methane is released into the atmosphere by a number of sources, both natural and anthropogenic (relating to human activity). The anthropogenic sources correspond to approximately $60 \%$ of global methane emissions and they include fossil fuel production, animal husbandry (enteric fermentation in livestock and manure management), rice paddies, biomass burning and landfills. The main natural sources of methane include wetlands, oceans, gas hydrates and termites $(14,18)$.

The microbial oxidation of methane in terrestrial environments is the only known net biological methane sink and the process consumes the equivalent of $1-10 \%$ of the total global emission of methane. Therefore, microbial oxidation of methane is a key regulator of the atmospheric concentrations of this important trace gas $(3,10)$.

There are many microorganisms that play important role in the natural environment. For instance, they contribute to the geological cycles of elements and transformation of natural chemicals, and they are responsible for decontamination and detoxification of polluted environments (15). Methylotrophic bacteria are among these types of microorganisms. They are able to oxidize one-carbon compounds, such as methane, methanol, methylated amines and halomethanes, as sources of carbon and energy for growth and hence, they are considered to be important regulators of atmospheric methane fluxes in nature $(3,5,12)$.

Methanotrophic bacteria, also named methane-oxidizing bacteria or methanotrophs, are a unique group of methylotrophic bacteria that are capable of using methane as a sole source of cellular carbon and energy. These microorganisms oxidize methane sequentially to methanol, formaldehyde, formate, and finally carbon dioxide $(1,5,16)$ :

$$
\mathrm{CH}_{4} \rightarrow \mathrm{CH}_{3} \mathrm{OH} \rightarrow \mathrm{HCHO} \rightarrow \mathrm{HCOOH} \rightarrow \mathrm{CO}_{2}
$$

The methanotrophic bacteria are divided into two main groups (types I and II) differing in a variety of aspects such as internal cellular structure, pathway of formaldehyde assimilation, which is the substance assimilated for producing cellular material, and predominant fatty acid chain length. Type I methanotrophs include the genera Methylomonas and Methylobacter and the type II methanotrophs include the genera Methylosinus and Methylocystis. A new group, type X, was added to accommodate methanotrophs similar to Methylococcus capsulatos, which has characteristics of both types I and II $(3,5,6)$.

The oxidation of methane by methanotrophs is initiated by a specific enzyme called methane monooxygenase (MMO). All known methanotrophs are capable to form a particulate or membrane-bound MMO (pMMO). However, the capability to form soluble or cytoplasmic MMO (sMMO) has been observed only in some type II methanotrophs (5). While methanotrophic bacteria are the only group of microorganisms capable to degrade methane, methane monooxigenase is also able to oxidize a variety of environmental pollutants, including trichloroethylene, dicloroethylene and naphthalene. Because of this characteristic, methanotrophic bacteria can be used for remediation of contaminated environments $(1,6-9,11)$.

The purpose of this article is to study the possible application of methanotrophic bacteria Methylosinus trichosporium OB3b in monitoring methods for methane. Thereby, it is important to determine the best conditions for the performance of these cells, and if they remain stable under variations of temperature, $\mathrm{pH}$ and amount of substrate, which are found in different environments.

\section{MATERIALS AND METHODS}

\section{Materials}

Methylosinus trichosporium OB3b was obtained from the Biotechnology Research Institute, Canada. The methane 2.5, with purity of $99.5 \%$, was provided by White Martins Industrials Gases SA. All Reagents were purchased from Vetec Química Fina Ltda. (Brazil). Optical densities were determined using a UV-Visible spectrophotometer (CAM SPEC M302). The electrochemical measurements for the reading of the $\mathrm{pH}$ values were determined through phmether (Digimed DM20). A commercial $\mathrm{CO}_{2}$ electrode, Model 95-02 (Thermo Orium) was used for $\mathrm{CO}_{2}$ measurements.

\section{Medium}

Nitrate mineral salts (NMS) medium of Cornish et al. (2) was used throughout the experiments. This medium had the following composition (g.L-1 ${ }^{-1}$ : $\mathrm{NaNO}_{3}, 0.85 ; \mathrm{KH}_{2} \mathrm{PO}_{4}, 0.53 ; \mathrm{Na}_{2} \mathrm{HPO}_{4}, 0.86$; $\mathrm{K}_{2} \mathrm{SO}_{4}, 0.174 ; \mathrm{MgSO}_{4} .7 \mathrm{H}_{2} \mathrm{O}, 0.037 ; \mathrm{CaCl}_{2} .2 \mathrm{H}_{2} \mathrm{O}, 0.007$; $\mathrm{ZnSO}_{4} .7 \mathrm{H}_{2} \mathrm{O}, 5.74 \times 10^{-4} ; \mathrm{MnSO}_{4} .4 \mathrm{H}_{2} \mathrm{O}, 4.46 \times 10^{-4} ; \mathrm{H}_{3} \mathrm{BO}_{3}$, $1.24 \times 10^{-4} ; \mathrm{CuSO}_{4} .5 \mathrm{H}_{2} \mathrm{O}, 2.5 \times 10^{-4} ; \mathrm{Na}_{2} \mathrm{MoO}_{4} .2 \mathrm{H}_{2} \mathrm{O}, 9.6 \times 10^{-5}$; $\mathrm{CoCl}_{2} .6 \mathrm{H}_{2} \mathrm{O}, 9.6 \times 10^{-5} ; \mathrm{KI}, 1.66 \times 10^{-4} ; \mathrm{FeSO}_{4} .7 \mathrm{H}_{2} \mathrm{O}, 1.12 \times 10^{-2}$; $\mathrm{H}_{2} \mathrm{SO}_{4}(2 \mu \mathrm{M})$. The $\mathrm{pH}$ of this medium was 6.5.

\section{Growth Conditions}

In all the experiments, the cultivation of the microorganism was performed in $250 \mathrm{~mL}$ erlenmeyers flasks containing $50 \mathrm{~mL}$ of culture medium (4) and a known volume of methane that was supplied by direct injection on media under specific conditions of temperature and in a rotary shaker (150 rpm). To obtain the initial inoculum, the cultivation was carried out at $30^{\circ} \mathrm{C}$ with volume of $40 \mathrm{~mL}(1.79 \mathrm{mmol})$ of methane under the same conditions listed above.

The cell growth was followed by measuring the optical density at $600 \mathrm{~nm}\left(\mathrm{OD}_{600}\right)$ in the beginning of the experiment $(0$ h) and for every six hours. Thus, $1.5 \mathrm{~mL}$ aliquots of the medium were collected by a syringe, at time zero and each six hours, until optical density reached a maximum value indicating the beginning of the stationary phase. 
The best biodegradation conditions of methane by $M$. trichosporium OB $3 \mathrm{~b}$ were studied for different initial concentrations of the microorganism, amount of substrate (methane), temperatures and $\mathrm{pH}$ values.

The experiments for different initial concentrations of inoculum and the analysis for different conditions of methane amount, temperature and $\mathrm{pH}$ were carried out in triplicate. The data were analyzed using Excel 2000 software and the averages values were used to generate the growth curves that were constructed as a function of the incubation time and the cellular concentration of the culture medium.

\section{Carbon Dioxide Determination}

Carbon dioxide, the end product of methane microbial oxidation, was quantified through a carbon dioxide electrode model 95-02 (Thermo Orion). This electrode uses a gaspermeable membrane to separate the sample solution from the electrode internal solution. Dissolved carbon dioxide in the sample solution diffuses through the membrane until an equilibrium is reached between the partial pressure of $\mathrm{CO}_{2}$ in the sample solution and the $\mathrm{CO}_{2}$ in the internal filling solution.

In all analytical procedures, a buffer solution was added to the standard solutions and to the samples to ensure that the $\mathrm{pH}$ was maintained between 4.8 to 5 required for the electrode operation and so that possible interferences were minimized.

For the carbon dioxide determination, the growth of $M$. trichosporium OB3b was conducted in conditions as ideal for its growth, and samples of $2.5 \mathrm{~mL}$ were collected at $0,18,24,36$, 48 and 60 hours, during the cell growth.

\section{RESULTS AND DISCUSSION}

\section{Growth Profiles of Methylosinus trichosporium OB3b}

\subsection{Growth of $M$. trichosporium OB3b for Different} Initial Concentrations of Inoculum

The aim of this study was to evaluate the effect of the inoculum size (initial concentration of inoculum) on the growth of M. trichosporium $\mathrm{OB} 3 \mathrm{~b}$ and thereby to determine which inoculum size should be employed to accelerate the process of methane biodegradation by the bacterium. This investigation occurred under specific conditions of methane amount, temperature $\left(30^{\circ} \mathrm{C}\right)$ and $\mathrm{pH}(6.5)$.

The proportion methane-air used in this step was 1:5 (v/v), lower than the proportion employed in the works done by Whittenbury et al. (17) and Fox et al. (4). Thus, in each flask of $250 \mathrm{~mL}, 50 \mathrm{~mL}$ was the volume occupied by NMS medium and the cells, and the $200 \mathrm{~mL}$ remaining were $40 \mathrm{~mL}$ ( $1.79 \mathrm{mmol})$ of methane and air.

The profiles of bacterial growth for different initial concentrations of inoculum studied $\left(0.0208 \mathrm{~g} . \mathrm{L}^{-1} ; 0.0481\right.$ g.L. $\mathrm{L}^{-1}$; 0.0700 g.L. $\mathrm{L}^{-1}$ and $0.1493 \mathrm{~g} . \mathrm{L}^{-1}$ ), over a period of 126 hours, were determined by the relationship (Equation 1) between optical density at $600 \mathrm{~nm}\left(\mathrm{OD}_{600}\right)$ and cellular concentration $(\mathrm{X})$ and they are presented in Fig. 1.

$$
X\left(g . L^{-1}\right)=\frac{\left(\mathrm{OD}_{600}-0,0141\right)}{3 \cdot 696}\left(\mathrm{r}^{2}=0,9948\right) \quad \text { Equation } 1
$$

In order to better evaluate and compare the characteristics of growth at differents inoculum size, the variations of cellular concentration $(\Delta \mathrm{X})$, the lag phase duration $\left(\Delta \mathrm{t}_{\mathrm{lag}}\right)$ and the exponential phase duration $\left(\Delta \mathrm{t}_{\text {exp }}\right)$ were calculated and described on the Table 1. According to $\Delta \mathrm{X}$ values, it is observed that for the initial inoculum concentration of $0.0700 \mathrm{~g} . \mathrm{L}^{-1}$, a larger amount of cells was produced on 126 hours of growth, which may show greater methane degradation at the same period of time.

Other observations that can be extracted from Table 1 are the duration time of the lag and exponential phases. Again, the best conditions for microorganism adaptation were obtained at initial cellular concentration of 0.0700 g. $\mathrm{L}^{-1}$, temperature of $30^{\circ} \mathrm{C}$, $\mathrm{pH}=6.5$ and $1.79 \mathrm{mmol}$ methane, once the duration time of the

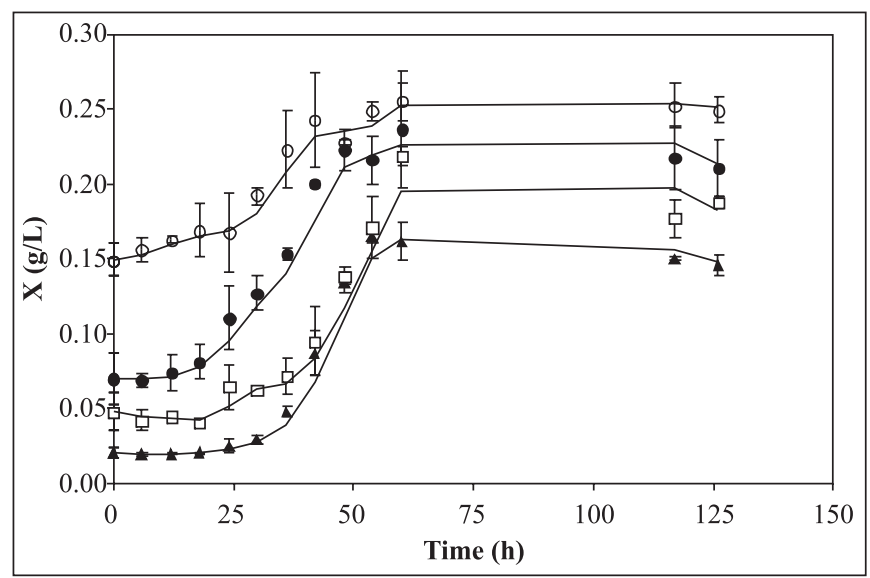

Figure 1. Cell concentration $(\mathrm{X})$ obtained for different initial concentrations of inoculum $\left(\mathrm{T}=30^{\circ} \mathrm{C}, \mathrm{pH}=6.5\right.$ and $1.79 \mathrm{mmol}$ methane).

Table 1. Growth kinetic parameters for different initial concentrations of inoculum $\left(\mathrm{T}=30^{\circ} \mathrm{C}, \mathrm{pH}=6.5,1,79 \mathrm{mmol}\right.$ of methane; $\mathrm{t}=126 \mathrm{~h}$ ).

\begin{tabular}{ccccc}
\hline & \multicolumn{4}{c}{ Initial Concentrations of Inoculum $\left(\mathrm{g.L}^{-1}\right)$} \\
\cline { 2 - 5 } Parameters & $\mathbf{0 , 0 2 0 8}$ & $\mathbf{0 , 0 4 8 1}$ & $\mathbf{0 , 0 7 0 0}$ & $\mathbf{0 , 1 4 9 3}$ \\
\hline$\Delta \mathrm{X}$ & 0,125 & 0,138 & 0,141 & 0,100 \\
$\Delta \mathrm{t}_{\mathrm{lag}}$ & $30 \mathrm{~h}$ & $24 \mathrm{~h}$ & $18 \mathrm{~h}$ & $24 \mathrm{~h}$ \\
$\Delta \mathrm{t}_{\mathrm{exp}}$ & $24 \mathrm{~h}$ & $36 \mathrm{~h}$ & $48 \mathrm{~h}$ & $36 \mathrm{~h}$ \\
\hline
\end{tabular}


adjustment phase (lag phase) was smaller. As for the variation of the exponential phase, in the same conditions, the $\Delta \mathrm{t}_{\exp }$ values showed that the microorganism stayed more time in the exponential phase of growth, demonstrating a greater potential for the degradation of methane. Therefore, the results imply that the inoculum size influences on the kinetics of methane biodegradation.

\subsection{Effect of Methane Concentration}

The application and use of the bacterium $M$. trichosporium OB3b for monitoring methane needs an important preliminary study of how this substance can influence the cellular metabolism of the microorganism. Thus, in this assay, the increase of initial methane concentration, from 1.79 to $2.69 \mathrm{mmol}$, was evaluated for initial cellular concentration of 0.0700 g.L. $\mathrm{pH} 6.5$ and temperature of $30^{\circ} \mathrm{C}$. The volume occupied by medium and cells remained the same $(50 \mathrm{~mL})$. The results for this both conditions are presented in Fig. 2.

As shown in Fig. 2, the increase of methane was a factor that inhibited the bacterial growth. A relevant explanation to this fact is based on the first stage of methane microbial oxidation by methanotrophic bacteria, which is catalyzed by the enzyme methane monooxigenase (MMO). Only one atom of molecular oxygen is incorporated into methanol; the other atom is released as water (8). This enzyme requires oxygen as a cofactor for performing the initial oxidation of methane (11). Thus, when the proportion methane-air was modified, the amount of available oxygen changed too, and consequently, this modification influenced the stage of methanol formation, which is one of intermediaries belonging to the route of the methane biodegradation by methanotrophs.

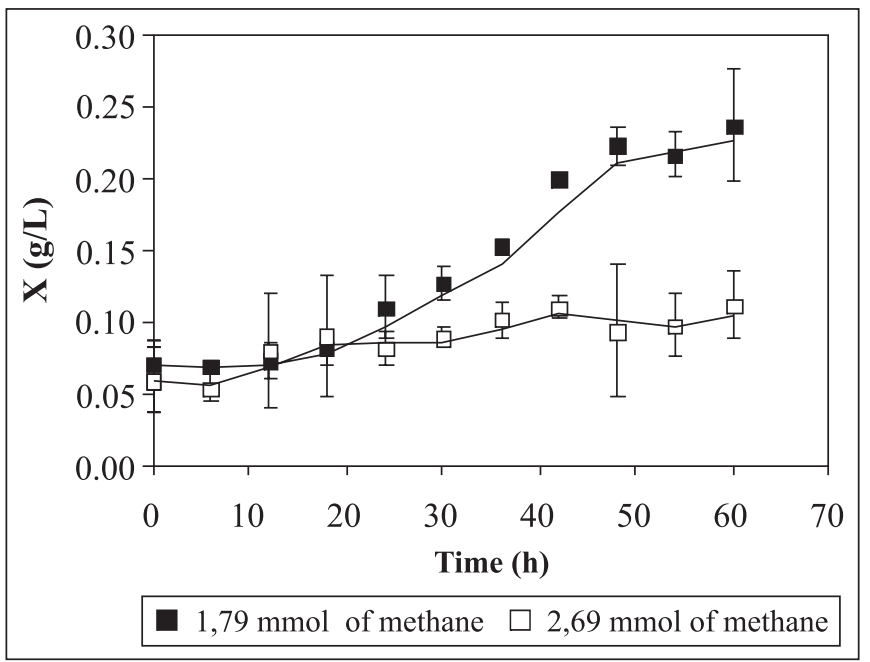

Figure 2. Effect of methane concentrations on the growth of $M$. trichosporium $\mathrm{OB} 3 \mathrm{~b}\left(\mathrm{Xo}=0.700 \mathrm{~g} \cdot \mathrm{L}^{-1} ; \mathrm{pH}=6.5\right.$ and $\left.\mathrm{T}=30^{\circ} \mathrm{C}\right)$.
Another explanation for the observed behavior can be based on the fact that, with the increase of methane concentration, the methanol production in the growth medium was more accelerated, and according to studies accomplished by Whittenbury et al. (17) and Cornish et al. (2), methanol is toxic to methanotrophic bacteria when presents in high concentrations. Therefore, the methanol generation might have inhibited the cellular metabolism of $M$. trichosporium $\mathrm{OB} 3 \mathrm{~b}$.

\subsection{Effect of Temperature}

In this assay, the behavior of cellular growth at temperatures of $20^{\circ} \mathrm{C}, 30^{\circ} \mathrm{C}$ and $40^{\circ} \mathrm{C}$ was evaluated for an initial cellular concentration of 0.0700 g.L $\mathrm{L}^{-1}, \mathrm{pH} 6.5$ and with $1.79 \mathrm{mmol}$ of methane.

As shown in Fig. 3, M. trichosporium OB3b was capable to biodegrade methane only at temperatures of $20^{\circ} \mathrm{C}$ and $30^{\circ} \mathrm{C}$. At $20^{\circ} \mathrm{C}$, the bacteria took a longer time for adapting to this condition. From Fig. 3, it is observed that the microorganism reached the growth phase (exponential phase) after 30 hours of cultivation, while at $30^{\circ} \mathrm{C}$, such fact happened after 18 hours. Thus, from this observation, it was concluded that the temperature of $30^{\circ} \mathrm{C}$ was best suited for the continuity of the experiments with of $M$. trichosporium $\mathrm{OB} 3 \mathrm{~b}$.

\subsection{Effect of $\mathrm{pH}$}

In the biodegradation process of methane by bacteria $M$. trichosporium $\mathrm{OB} 3 \mathrm{~b}$, methane is oxidized to carbon dioxide forming, as intermediaries, methanol, formaldehyde, and formic acid:

$$
\mathrm{CH}_{4} \rightarrow \mathrm{CH}_{3} \mathrm{OH} \rightarrow \mathrm{HCHO} \rightarrow \mathrm{HCOOH} \rightarrow \mathrm{CO}_{2}
$$

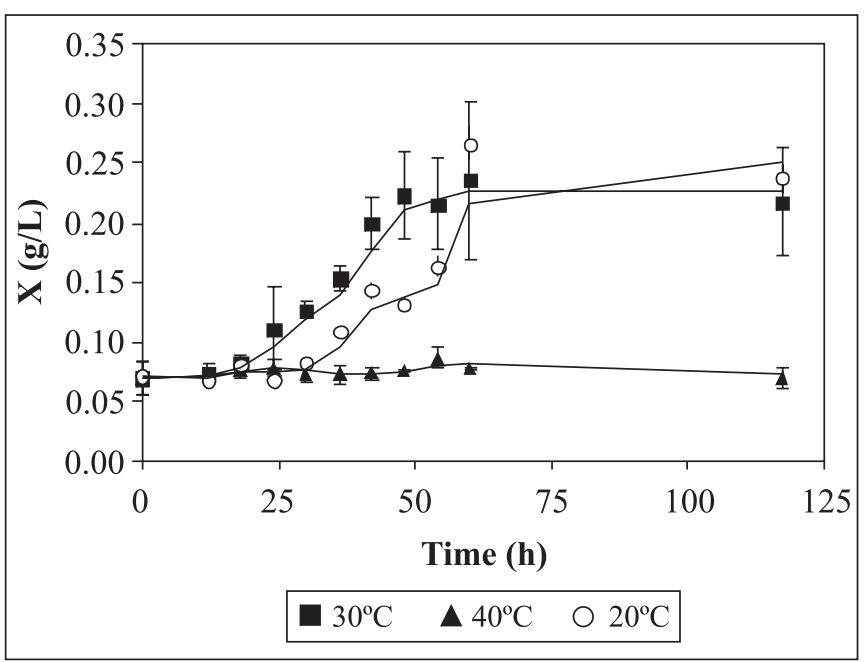

Figure 3. Effect of temperature on the growth of $M$. trichosporium $\mathrm{OB} 3 \mathrm{~b}\left(\mathrm{Xo}=0.0700 \mathrm{~g} . \mathrm{L}^{-1} ; \mathrm{pH}=6.5\right.$ and $1.79 \mathrm{mmol}$ of methane $)$. 
The employed electrode for $\mathrm{CO}_{2}$ analysis presents as a prerequisite the use of samples in a $\mathrm{pH}$ range between 4.8 and 5.2 for ensuring that all bicarbonate or carbonate, possibly present, would be converted to carbon dioxide. Therefore, in these experiments, the cultivation media NMS was acidified before the stage of cellular growth, until those required $\mathrm{pH}$ values were reached.

For an initial cell concentration of 0.0700 g.L.- , temperature of $30^{\circ} \mathrm{C}$ and $1.79 \mathrm{mmol}$ of methane, the behavior of $M$. trichosporium $\mathrm{OB} 3 \mathrm{~b}$ growth was studied on $\mathrm{pH}$ values of 4.8 and 5.2, in addition to the $\mathrm{pH} 6.5$, in previous experiments. The results are shown in Fig. 4.

From the results, it is noticed that there is no metabolic activity for acid values of $\mathrm{pH}$. According to Whittenbury et al. (17), all methanotroph strains grow over a $\mathrm{pH}$ range of 5.8 to 7.4, and $\mathrm{pH}$ values of 6.6 to 6.8 appear to be the optimum for growth rate. Studies accomplished by Dianou and Adachi (3) report that $M$. trichosporium $\mathrm{OB} 3 \mathrm{~b}$ presents metabolic activity in $\mathrm{pH}$ range of 5.5 to 9 , and that optimum $\mathrm{pH}$ is between 6.5 and 7.0. The results, obtained in this work, are thus in accordance to the related in the literature.

\section{Study of Kinetic Parameters for Growth of M. trichosporium OB3b}

The characteristic kinetic parameters of growth profile of $M$. trichosporium $\mathrm{OB} 3 \mathrm{~b}$ were determined under the conditions of temperature at $30^{\circ} \mathrm{C}$, $\mathrm{pH}$ of 6.5 and with $1.79 \mathrm{mmol}$ of methane for each experiment using different initial cellular concentrations of inoculum.

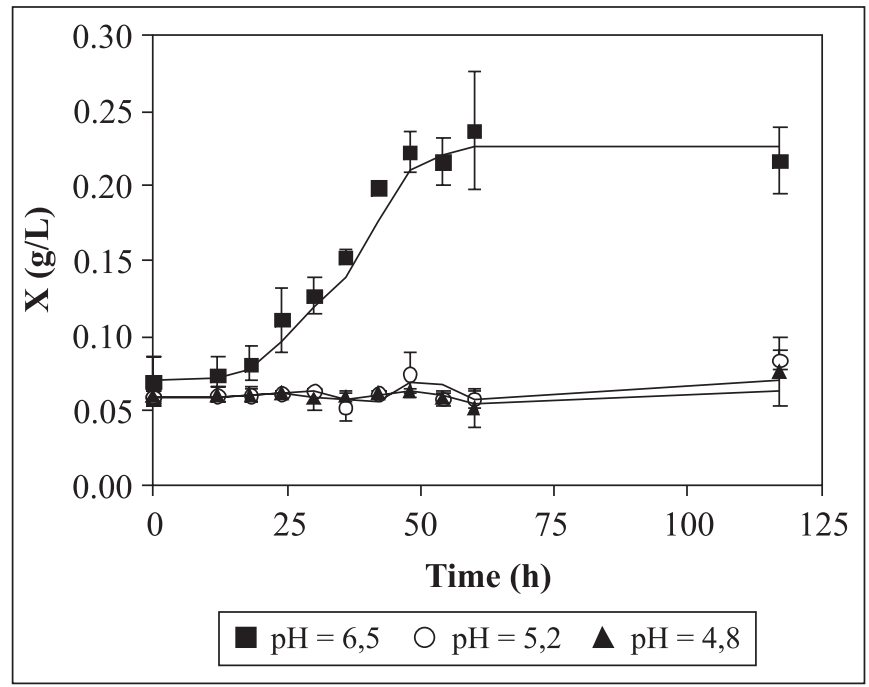

Figure 4. Effect of $\mathrm{pH}$ on growth of $M$. trichosporium $\mathrm{OB} 3 \mathrm{~b}$ $\left(\mathrm{Xo}=0.0700 \mathrm{~g} \cdot \mathrm{L}^{-1}, \mathrm{~T}=30^{\circ} \mathrm{C}\right.$ and $1.79 \mathrm{mmol}$ of methane).
The following parameters were calculated: the specific growth rate $\left(\mu_{\mathrm{X}}\right)$, that indicates the increase in biomass per time unit and it is determined from the exponential phase (equation $2)$; the theoretical and process biomass yields $\left(\mathrm{Y}_{\mathrm{X} / \mathrm{S}}\right)$, determined as the mass of biomass produced by the mass of methane added to the medium (equation 3); the efficiency ( $\eta$ ), obtained through the relationship among the theoretical and process biomass yields (equation 4); and volumetric productivity $\left(\mathrm{Q}_{\mathrm{P}}\right)$, determined by dividing the final biomass concentration by the time (h) required to achieve complete methane utilization (equation 5). The calculed results for these growth parameters are reported in Table 2.

$$
\begin{array}{ll}
\mu_{X}=\frac{1}{X} \frac{d X}{d t} & \text { Equation 2 } \\
Y_{X / S}=\frac{M_{X f}-M_{X o}}{M_{S o}-M_{S f}} & \text { Equation 3 } \\
\eta=\frac{Y_{X / S}(\text { process })}{Y_{X / S}(\text { theoretical })} \cdot 100 & \text { Equation 4 } \\
Q_{P}=\frac{\Delta X}{\Delta t} & \text { Equation 5 }
\end{array}
$$

In the analysis of methane biodegradation by $M$. trichosporium $\mathrm{OB} 3 \mathrm{~b}$, the identification of the best conditions shows when this microorganism is indeed capable of the consumption of substrate (methane) in a fast way, reaching the exponential growth phase in smaller time. This observation is of great importance for the development of methane biossensor, since one of desirable characteristics for biosensor application is the obtaining of a fast analysis. Thus, the best conditions of

\begin{tabular}{|c|c|c|c|c|}
\hline \multirow[t]{2}{*}{ Parameter } & \multicolumn{4}{|c|}{$\begin{array}{l}\text { Initial Cellular Concentration } \\
\left.\text { of Inoculum (g.L } \mathrm{L}^{-1}\right)\end{array}$} \\
\hline & 0.0208 & 0.0481 & 0.0700 & 0.1493 \\
\hline$\mu_{\mathrm{X}}\left(\mathbf{h}^{-1}\right)$ & 0.0691 & 0.0407 & 0.0324 & 0.0209 \\
\hline $\begin{array}{l}\mathbf{Y}_{\mathrm{X} / \mathrm{s}}(\text { theoretical }) \\
\left(\mathrm{g}_{\text {cells }} / \mathrm{g}_{\mathrm{CH} 4}\right)\end{array}$ & 1.014 & 0.9660 & 0.9279 & 0.7897 \\
\hline $\begin{array}{c}\mathbf{Y}_{\mathrm{X} / \mathrm{s}}(\text { process }) \\
\left(\mathrm{g}_{\text {cells }} / \mathbf{g}_{\mathrm{CH} 4}\right)\end{array}$ & 0.8878 & 0.7762 & 0.6830 & 0.3261 \\
\hline$\eta(\%)$ & 87.84 & 80.54 & 73.73 & 41.38 \\
\hline$Q_{P}\left(10^{-3}\right.$ g/L.h $)$ & 2.3448 & 2.8410 & 2.7732 & 1.7632 \\
\hline
\end{tabular}

Table 2. Calculed kinetic parameters for different initial concentrations of inoculum $\left(\mathrm{pH}=6.5, \mathrm{~T}=30^{\circ} \mathrm{C}\right.$, and $1.79 \mathrm{mmol}$ of methane). 
methane biodegradation by $M$. trichosporium OB3b were observed in the experiments developed with initial cellular concentration of $0.0700 \mathrm{~g} . \mathrm{L}^{-1}$, temperature of $30^{\circ} \mathrm{C}, \mathrm{pH} 6.5$ and with $1.79 \mathrm{mmol}$ of methane, although, in this situation, the best values do not have been observed for specific growth rate, biomass yield and efficiency.

\section{Analysis of Methane Biodegradation Using a $\mathrm{CO}_{2}$ Sensor}

In this phase, cultivations of $M$. trichosporium OB3b were performed under conditions established the best for microorganism growth: initial cellular concentration of 0.0700 g. $\mathrm{L}^{-1}$, temperature of $30^{\circ} \mathrm{C}, \mathrm{pH} 6.5$ and $1.79 \mathrm{mmol}$ of methane. The amount of carbon dioxide generated by methane biodegradation, during a growth period of 60 hours, was determined using the carbon dioxide sensor. The $\mathrm{CO}_{2}$ measurements were used for the calculation of methane consumed.

According to Whittenbury et al. (17) for each mol of methane consumed in the biodegradation process, 0.2 to $0.3 \mathrm{~mol}$ of carbon dioxide mol is formed. Thus, it was assumed that for each mol of $\mathrm{CH}_{4}$ consumed (16g), $0.25 \mathrm{~mol}$ of $\mathrm{CO}_{2}$ was produced $(11 \mathrm{~g})$. The Equation 6 established this relationship and it was used to determine the amount of methane consumed in 60 hours. In this equation, the amount of $\mathrm{CO}_{2}$ produced was determined using the carbon dioxide sensor.

\section{$\mathrm{CH}_{4}$ consumed $(\mathrm{mg})=1,45 \times \mathrm{CO}_{2}$ produced $(\mathrm{mg}) \quad$ Equation 6}

The conversion percentage $(P)$ of $\mathrm{CH}_{4}$ in $\mathrm{CO}_{2}$ during the biodegradation process was calculated through the relationship between the amount of methane consumed and the initial amount $(28.68 \mathrm{mg}$ ) of methane used in the experiments (Equation 7). The values obtained for carbon dioxide generated, methane consumed and conversion percentage are described in Table 3.

$$
P=\frac{\mathrm{CH}_{4} \text { consumed }(\mathrm{mg})}{\mathrm{CO}_{2} \text { produced }(\mathrm{mg})} \times 100 \quad \text { Equation } 7
$$

Table 3. Conversion percentage $\mathrm{CH}_{4} / \mathrm{CO}_{2}(P)\left(\mathrm{Xo}=0.0700\right.$ g.L. $\mathrm{L}^{-1}$; $\mathrm{T}=30^{\circ} \mathrm{C} ; \mathrm{pH}=6.5$ and $1.79 \mathrm{mmol}$ of initial methane $(28.68 \mathrm{mg})$ ).

\begin{tabular}{cccc}
\hline Time (h) & $\begin{array}{c}\text { Amount of } \mathrm{CO}_{2} \\
\text { produced }(\mathbf{m g})\end{array}$ & $\begin{array}{c}\text { Amount of } \mathbf{C H}_{\mathbf{4}} \\
\text { consumed }(\mathbf{m g})\end{array}$ & $\boldsymbol{P ( \% )}$ \\
\hline 0 & 0.158433 & 0.229728 & 0.801 \\
18 & 0.260014 & 0.377020 & 1.31 \\
24 & 0.463177 & 0.671606 & 2.34 \\
36 & 0.564758 & 0.818899 & 2.86 \\
48 & 0.632479 & 0.917094 & 3.20 \\
60 & 0.683270 & 0.990741 & 3.45 \\
\hline
\end{tabular}

The Fig. 5 shows the results of amount of carbon dioxide generated and amount of methane consumed, presented in Table 3 , with amount of biomass produced for a period of $60 \mathrm{~h}$, under the conditions studied in this experiment.

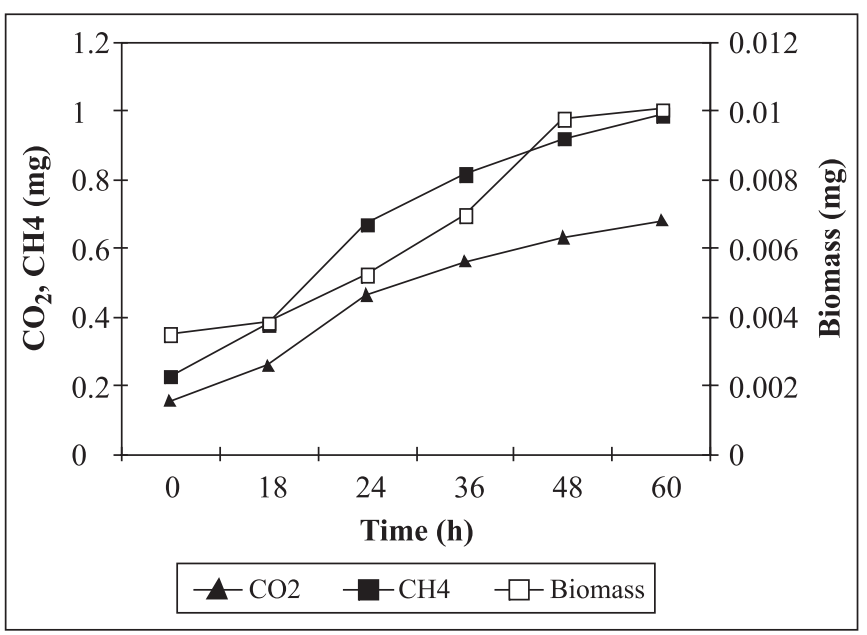

Figure 5. Results obtained of $\mathrm{CH}_{4}$ consumed ( $\left.\square\right), \mathrm{CO}_{2}$ produced $(\boldsymbol{\Delta})$ and biomass produced $(\square)\left(\mathrm{Xo}=0.0700 \mathrm{~g} . \mathrm{L}^{-1}, \mathrm{~T}=30^{\circ} \mathrm{C}, \mathrm{pH}\right.$ $=6.5$ and $1.79 \mathrm{mmol}$ of methane).

\section{CONCLUSIONS}

The best conditions for methane biodegradation by the bacterium M. trichosporium OB3b occurred at an inoculum cellular concentration of $0.0700 \mathrm{~g} . \mathrm{L}^{-1}$, a methane-air proportion of $1: 5$ (for a system with $20 \%$ medium), temperature of $30^{\circ} \mathrm{C}$ and $\mathrm{pH}$ equal to 6.5. In these conditions, a smaller time duration of the lag phase and a wider exponential phase of growth were observed. The maximum and minimum standard deviations did not exceed, respectively, the values of $1.0 \%$ and $9.7 \%$ in all experiments performed.

The best results for some kinetic parameters were not obtained in the more adequate conditions of methane biodegradation by the bacterium M. trichosporium OB3b. This can be explained by the fact that has an objective to find the conditions of initial cell concentration, amount of methane, temperature and $\mathrm{pH}$ which occurred a more efficient adaptation of the bacterium, which was noticed by reducing the duration time of the lag phase. The purpose of employment of microorganism M. trichosporium OB3b in the manufacture of the biosensor is to have a sensitive response in the shortest possible time, which is reached when it shows minor duration time of lag phase. These results should be taken into consideration for the employment of $M$. trichosporium $\mathrm{OB} 3 \mathrm{~b}$ in monitoring methods, and its application as biological component in a microbial biossensor of methane. 


\section{RESUMO}

\section{Análise da biodegradação de metano por Methylosinus trichosporium OB3b}

A oxidação microbiológica de metano na atmosfera é realizada por bactérias metanotróficas, que o utilizam como fonte única de carbono e energia. O objetivo deste trabalho consistiu na investigação das melhores condições de biodegradação do metano por bactérias metanotróficas Methylosinus trichosporium $\mathrm{OB} 3 \mathrm{~b}$, que o oxidam a dióxido de carbono, para o emprego destes microrganismos em métodos de monitoração para metano. Os resultados obtidos mostraram que $M$. trichosporium OB3b foi capaz de degradar o metano de forma mais eficaz partindo-se de uma concentração inicial de microrganismos de 0.0700 g. $\mathrm{L}^{-1}$, a uma temperatura de $30^{\circ} \mathrm{C}, \mathrm{pH}$ igual a 6.5 e empregando-se $1.79 \mathrm{mmol}$ de metano. Nestas mesmas condições, não houve crescimento bacteriano quando foram empregados $2.69 \mathrm{mmol}$ de metano. A taxa específica de crescimento do microrganismo, o fator de conversão, a eficiência e a produtividade volumétrica para as condições otimizadas de biodegradação foram, respectivamente, $0.0324 \mathrm{~h}^{-1}, 0.6830$ gcélulas $/ \mathrm{gCH}_{4}, 73.73 \%$ e $2.7732 .10^{-3}$ gcélulas/L.h. O produto final da degradação microbiológica do metano, o dióxido de carbono, foi quantificado através do emprego de um eletrodo comercial, e, através desta medida, foi calculado o percentual de conversão de metano em dióxido de carbono.

Palvras-chave: metano, biodegradação, bactérias metanotróficas, Methylosinus trichosporium OB3b.

\section{REFERENCES}

1. Bodrossy, L.; Murrell, J.C.; Dalton, H.; Kalman, M.; Puskas, L.G.; Kovacs, K.L. (1995). Heat-Tolerant Methanotrophic Bacteria from the Hot Water Effluent of a Natural Gas Field. Appl. Environ. Microbiol., 61 (10), 3549-3555.

2. Cornish, A.; Nicholls, K.M.; Hunter, B.K.; Aston, W.J.; Higgins, I.J.; Sanders, K.M. (1984). In vivo ${ }^{13} \mathrm{C}$ NMR investigations of methanol oxidation by the obligate methanotroph Methylosinus trichosporium OB3b. J. Gen. Microbiol., 130, 2565-2575.
3. Dianou, D.; Adachi, K. (1999). Characterization of methanotrophic bacteria isolated from a subtropical paddy field. FEMS Microbiol. Lett., 173, 163-173.

4. Fox, B.G.; Froland, W.A.; Jollie, D.R.; Lipscomb, J.D. (1990). Methane Monooxygenase from Methylosinus trichosporium OB3b. Methods Enzymol., 188, 195-196.

5. Hanson, R.S.; Hanson, T.E. (1996). Methanotrophic Bacteria. Microbiol Rev., 60 (2), 439-471.

6. Lontoh, S.; Semrau, J.D. (1998). Methane and Trichloroethylene Degradation by Methylosinus trichosporium OB3b Expressing Particulate Methane Monooxygenase. Appl. Environ. Microbiol., 64 (3), 1106-1114.

7. Martin, H.; Murrell, J.C. (1995). Methane monooxygenase mutants of Methylosinus trichosporium constructed by marker-exchange mutagenesis. FEMS Microbiol. Lett., 127, 243-248.

8. Nicolaidis, A.A.; Sargent, A.W. (1987). Isolation of Methane Monooxygenase-Deficient Mutants from Methylosinus trichosporium OB3b Using Dichloromethane. FEMS Microbiol. Lett., 41, 47-52.

9. Pacheco-oliver, M.; McDonald, I.R.; Groleau, D.; Murrel, C.; Miguez, C.B. (2002). Detection of Methanotrophs with Highly Divergent pmoA Genes from Arctic Soils. FEMS Microbiol. Lett., 209, 313-319.

10. Roslev, P.; Iversen, N. (1999). Radioactive Fingerprinting of Microorganisms that Oxidize Atmospheric Methane in Different Soils. Appl. Environ. Microbiol., 65 (9), 4064-4070.

11. Speitel, G.E.; Thompson, R.C.; Weissman, D. (1993). Biodegradation Kinetics of Methylosinus Trichosporium OB3b at Low Concentrations of Chloroform in the Presence and Absence of Enzyme Competition by Methane. Wat. Res., 27 (1), 5-24.

12. Sullivan, J.P.; Dickinson, D.; Chase, H.A. (1998). Methanotrophs, Methylosinus trichosporium OB3b, sMMO, and their Application to Bioremediaton. Crit. Rev. Microbiol., 24 (4), 335-373.

13. Tohjima, Y.; Wakita, H. (1994). Development of a Continuous Measurement System and Areal Distribution of Methane in Some Source Areas. Appl. Geochem., 9, 141-146.

14. U.S. Environmental Protection Agency. 2005. Methane. Available at http://www.epa.gov/methane/scientific.html. Accessed July 2005.

15. Watanabe, K. (2002). Linking Genetics, Physiology and Ecology: an Interdisciplinary Approach for Advancing Bioremediation. $J$. Biosci. Bioeng., 94 (6), 557-562.

16. Whalen, S.C. (2005). Biogeochemistry of Methane Exchange between Natural Wetlands and the Atmosphere. Environ. Eng. Sci., 22 (1), 73-93.

17. Whittenbury, R.; Phillips, K.C.; Wilkinson, J.F. (1970). Enrichment, Isolation and Some Properties of Methane-utilizing Bacteria. J. Gen. Microbiol., 61, 205-218.

18. Wuebbles D.J.; Hayhoe K. (2000). Atmospheric methane: trends and impacts. In: Ham, J.V.; Baede, A.P.M.; Meyer, L.A.; Ybema, R. (eds.). Non- $\mathrm{CO}_{2}$ Greenhouse Gases: Scientific Understanding, Control and Implementation. Kluwer Academic Press, Netherlan, p.1-14. 